\title{
Article \\ Phytoplankton Biodiversity in Two Tropical, High Mountain Lakes in Central Mexico
}

\author{
Estela Cuna ${ }^{1}$, Javier Alcocer ${ }^{1, *(0)}$, Martha Gaytán ${ }^{1}$ and Margarita Caballero ${ }^{2}$ \\ 1 Grupo de Investigación en Limnología Tropical, Facultad de Estudios Superiores Iztacala, \\ Universidad Nacional Autónoma de México, Av. de los Barrios No.1, Los Reyes Iztacala, \\ Tlalnepantla 54090, Mexico; ecuna@unam.mx (E.C.); martha.iztacala.unam@gmail.com (M.G.) \\ 2 Instituto de Geofísica, Universidad Nacional Autónoma de México, Ciudad Universitaria, \\ Coyoacán 04510, Mexico; maga@igeofisica.unam.mx \\ * Correspondence: jalcocer@unam.mx
}

check for updates

Citation: Cuna, E.; Alcocer, J.; Gaytán, M.; Caballero, M.

Phytoplankton Biodiversity in Two Tropical, High Mountain Lakes in Central Mexico. Diversity 2022, 14, 42. https://doi.org/10.3390/d14010042

Academic Editors: Michael Wink, Paolo Pastorino and Marino Prearo

Received: 12 November 2021

Accepted: 7 January 2022

Published: 10 January 2022

Publisher's Note: MDPI stays neutral with regard to jurisdictional claims in published maps and institutional affiliations.

Copyright: (c) 2022 by the authors. Licensee MDPI, Basel, Switzerland. This article is an open access article distributed under the terms and conditions of the Creative Commons Attribution (CC BY) license (https:// creativecommons.org/licenses/by/ $4.0 /)$.

\begin{abstract}
Lakes El Sol and La Luna, inside the crater of the Nevado de Toluca volcano, Central Mexico, are the only two perennial high mountain lakes [HML] in the country. HML are considered among the most comparable ecosystems worldwide. These lakes are "extreme" environments with diluted, oligotrophic, and cold waters exposed to high UV radiation doses. In this paper, we document the phytoplankton species inhabiting these two extreme tropical ecosystems. The phytoplankton diversity of Lakes El Sol and La Luna is low compared to the global phytoplankton diversity from other Mexican inland waters. Nonetheless, the phytoplankton diversity turned out to be high compared to other HML worldwide, both temperate and tropical. The phytoplankton community in Lake El Sol was formed by 92 morphospecies and in Lake La Luna by 63; in both, the most diverse groups were Bacillariophyceae and Chlorophyceae. All species found in Lake La Luna were present in Lake El Sol, but 29 species present in Lake El Sol were absent in Lake La Luna. Nevertheless, $57 \%$ of the most frequent and abundant taxa in Lake El Sol were rare in La Luna, and $47 \%$ of the most frequent and abundant taxa in Lake La Luna were rare in Lake El Sol. Associated with their shallowness and polymictic thermal pattern, $87.5 \%$ of the Bacillariophyceae morphospecies are tychoplantonic, while the remaining $12.5 \%$ are truly planktonic. Dominant taxa were Chlorophyceae in Lake El Sol and Cyanobacteria in Lake La Luna. The most extreme conditions of Lake La Luna (ultraoligotrophy, very low $\mathrm{pH}$, high ultraviolet radiation) most likely explained the differences in the dominant species composition and lower species richness compared to Lake El Sol. Herein, we provide for the first time a taxonomic list of the phytoplankton community of Lakes El Sol and La Luna. This information constitutes a baseline needed to use these HML as sentinels of global and climate change.
\end{abstract}

Keywords: taxonomic richness; density; biomass; alpine lakes; Nevado de Toluca; El Sol and La Luna

\section{Introduction}

Phytoplankton biodiversity responds to multiple stressors. The size of the lakes usually associated with habitat diversity correlates positively with phytoplankton species richness [1-3]. In contrast, phytoplankton species richness decreases as the trophic status increases [4-6], with higher doses of UV radiation [7,8], acidification [9,10], and fish introduction [11,12].

High mountain lakes [HML] have recently attracted scientific attention because they are extremely sensitive ecosystems to global changes $[13,14]$. The harsh conditions prevailing in HML [e.g., diluted, oligotrophic and cold waters, high UV radiation doses] classify these water bodies as extreme aquatic environments [15-17].

Catalan and Donato Rondón [18] consider HML among the most comparable ecosystems in the world, despite the climatic differences related to latitude and the uneven volcanic influence in some areas. Unfortunately, most of the limnological research on HML 
has been done mainly in temperate areas, and comparatively few studies have so far been undertaken in HML of tropical latitudes [19], such as Mexico.

Mexico is considered a megadiverse country, one of the few that possess, all together, $70 \%$ of the vertebrate and vascular plant diversity worldwide [20]. However, little is known about the diversity of Mexican freshwaters, phytoplankton included, and it is unknown whether these ecosystems present the same trend of higher tropical biodiversity (latitudinal diversity gradient) that terrestrial communities show [21].

El Sol and La Luna are the only HML in the expanse between Panama and southern USA, located at the northern edge of the Neotropical region. These lakes are about $600 \mathrm{~m}$ away from each other, inside the crater of the Nevado de Toluca volcano, and they have the same origin, climate, and water regime [22]. Despite their closeness and similar geologic context, they differ in physical and chemical characteristics [23] and in their biological communities known so far (e.g., zooplankton and macrobenthos) [24-27]; nonetheless, their phytoplankton communities remained scarcely and inaccurately described.

Löffler [28] made the first study on the limnology and plankton composition of these two lakes, which were followed by further taxonomic, ecological, and paleolimnological investigations by Caballero [29], Banderas-Tarabay [30], Alcocer et al. [23], and Cuna et al. [31]. However, these works did not provide comprehensive data on their phytoplankton biodiversity, and many questions about their ecology remained open. Herein, we provide for the first time a taxonomic list of the phytoplankton communities of Lakes El Sol and La Luna. Moreover, the present study comparatively analyzes the phytoplankton biodiversity of these two unique tropical HML and provides insights into the differences found. This information constitutes a necessary baseline for future studies, which could evaluate possible changes in phytoplankton species in these lakes.

Considering that species diversity of terrestrial ecosystems increases in the tropics, and since recent studies on temperate HML, e.g., [16], have shown that they hold a rich eukaryotic planktonic community, we hypothesized that tropical HML El Sol and La Luna would display higher phytoplanktonic diversity compared to their temperate equivalents. Additionally, considering that phytoplankton responds to stressors, such as lake size, trophic status, acidification, and ultraviolet radiation, the biodiversity will be lower in Lake La Luna compared to Lake El Sol because of its smaller size, ultraoligotrophic status, more acidic $\mathrm{pH}$, and higher doses of ultraviolet radiation.

\section{Materials and Methods}

\subsection{Study Area}

El Sol and La Luna crater lakes $\left(19^{\circ} 06^{\prime} \mathrm{N}, 99^{\circ} 45^{\prime} \mathrm{W}, 4200 \mathrm{~m}\right.$ a.s.l.) are around $80 \mathrm{~km}$ W-SW from Mexico City in the Central Mexican Volcanic Belt (Figure 1). Climate is cold alpine with monthly mean temperatures ranging between $2.8^{\circ} \mathrm{C}$ in February and $5.8^{\circ} \mathrm{C}$ in April [32]. Total annual precipitation is $1244 \mathrm{~mm}$, concentrated between June and September and ranging from $17 \mathrm{~mm}$ in December to $270 \mathrm{~mm}$ in July [32]. The maximum depth of lake El Sol is $15 \mathrm{~m}$, with a surface area of approximately $230,000 \mathrm{~m}^{2}$, whereas that of lake La Luna is $10 \mathrm{~m}$, with a surface area of $30,500 \mathrm{~m}^{2}$. Both lakes are warm polymictic; La Luna is continuous, while $\mathrm{El} \mathrm{Sol}$ is discontinuous, displaying frequent mixing events throughout the year [33]. Oligotrophic Lake El Sol displays lower transparency, and higher electric conductivity, $\mathrm{pH}$, phosphorus, chlorophyll-a, and seston concentrations than ultraoligotrophic Lake La Luna (Table 1). In contrast, La Luna has higher nitrogen, particularly nitrate, concentrations than El Sol [22,23]. 


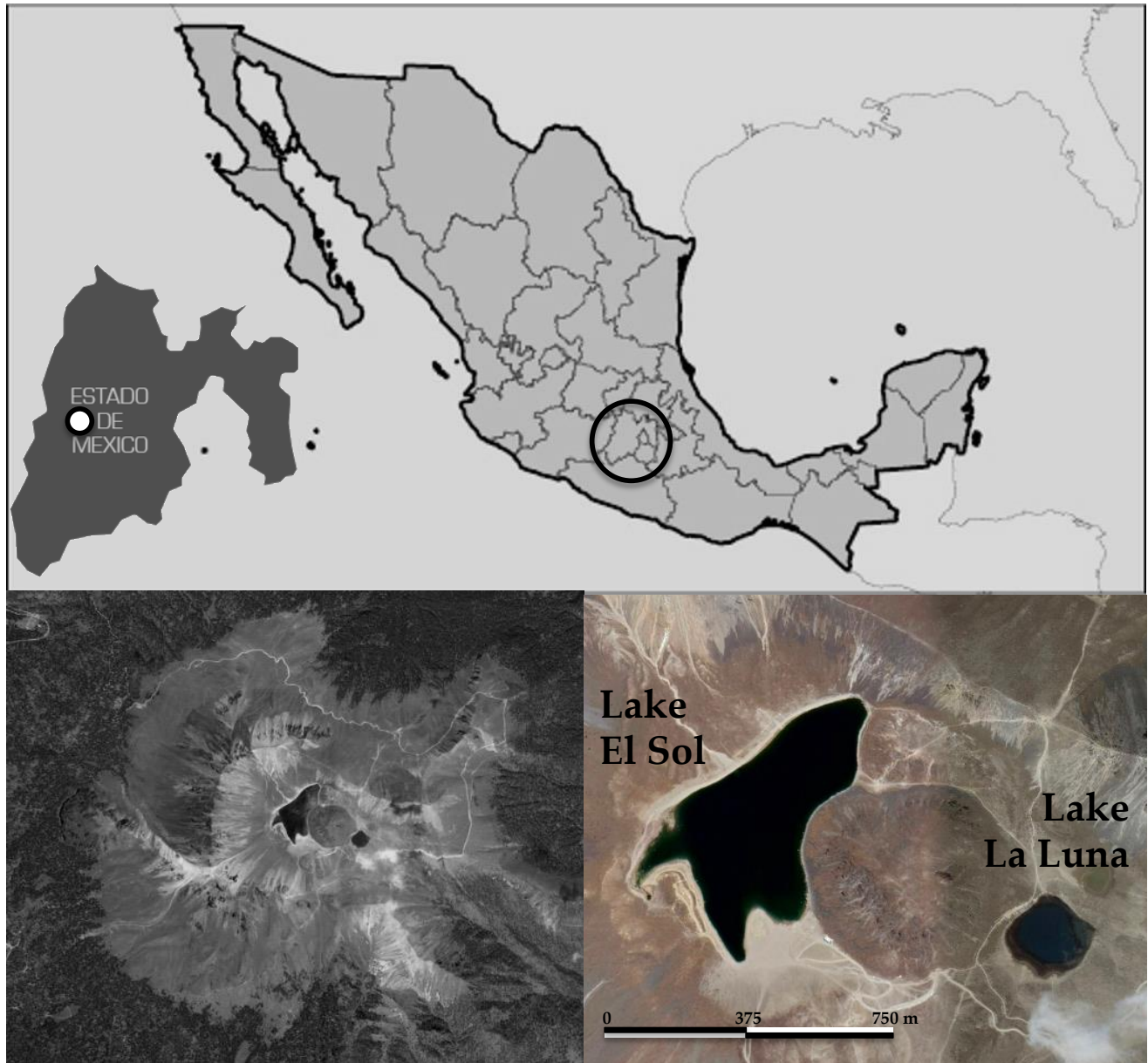

Figure 1. Lakes El Sol and La Luna [lower panels], the Estado de Mexico and Mexico [upper panel].

Table 1. Environmental variables (average \pm standard deviation, minimum, maximum) of Lakes El Sol and La Luna, Nevado de Toluca. (Temp = temperature, DO = dissolved oxygen, $\mathrm{K}_{25}=$ electrical conductivity, \%SPAR = percentage of photosynthetic active radiation (PAR) at the bottom, ${\mathrm{N}-\mathrm{NO}_{2}}_{2}$ nitrogen as nitrites, $\mathrm{N}-\mathrm{NO}_{3}=$ nitrogen as nitrates, $\mathrm{N}_{-} \mathrm{NH}_{4}=$ nitrogen as ammonium, $\mathrm{DIN}=$ dissolved inorganic nitrogen, $\mathrm{P}-\mathrm{SRP}=$ phosphorous as soluble reactive phosphorous, $\mathrm{Si}-\mathrm{SRSi}=$ silica as soluble reactive silica, $\mathrm{Chl}-\mathrm{a}=$ chlorophyll a). [* Statistically different $(\alpha<0.05)]$. (Data from [22,23]).

\begin{tabular}{|c|c|c|c|c|c|c|}
\hline \multirow{2}{*}{ Variable } & \multicolumn{3}{|c|}{ Lake El Sol } & \multicolumn{3}{|c|}{ Lake La Luna } \\
\hline & $X \pm$ s.d. & Min & Max & $X \pm$ s.d. & Min & MAX \\
\hline $\operatorname{Temp}\left({ }^{\circ} \mathrm{C}\right)$ & $9.2 \pm 1.5$ & 5.2 & 10.81 & $8.5 \pm 1.7$ & 5.7 & 10.9 \\
\hline $\mathrm{DO}\left(\mathrm{mg} \mathrm{L}^{-1}\right)$ & $6.6 \pm 0.6$ & 5.76 & 7.74 & $6.8 \pm 0.8$ & 5.9 & 8.6 \\
\hline $\mathrm{pH}^{*}$ & $5.5 \pm 0.3$ & 4.9 & 6.1 & $4.7 \pm 0.3$ & 4.5 & 5.6 \\
\hline $\mathrm{K}_{25}\left(\mu \mathrm{S} \mathrm{cm}^{-1}\right) *$ & $16 \pm 1$ & 15 & 18 & $14 \pm 0.8$ & 13 & 15 \\
\hline$\%$ SPAR * & $10 \pm 5$ & 3 & 26 & $44 \pm 12$ & 17 & 53 \\
\hline $\mathrm{N}-\mathrm{NO}_{2}\left(\mu \mathrm{g} \mathrm{L}^{-1}\right) *$ & $1.9 \pm 0.4$ & 0.56 & 4.3 & $0.5 \pm 0.2$ & 0.3 & 1.0 \\
\hline $\mathrm{N}-\mathrm{NO}_{3}\left(\mu \mathrm{g} \mathrm{L}^{-1}\right)$ * & $66.0 \pm 44.3$ & 1.26 & 138 & $316.7 \pm 28.0$ & 278.7 & 362.6 \\
\hline $\mathrm{N}-\mathrm{NH}_{4}\left(\mu \mathrm{g} \mathrm{L}^{-1}\right)$ & $38.1 \pm 21.4$ & 15.0 & 77.1 & $39.0 \pm 20.7$ & 15.0 & 77.1 \\
\hline $\operatorname{DIN}\left(\mu \mathrm{g} \mathrm{L}^{-1}\right)^{*}$ & $106.7 \pm 57.7$ & 16.9 & 185 & $356.4 \pm 23.6$ & 299.3 & 368.7 \\
\hline P-SRP $\left(\mu \mathrm{g} \mathrm{L}^{-1}\right)$ & $5.8 \pm 3.6$ & 1.1 & 11.1 & $4.0 \pm 4.5$ & 0.4 & 17.2 \\
\hline Si-SRSi $\left(\mu \mathrm{g} \mathrm{L}^{-1}\right)$ * & $68.9 \pm 56.6$ & 23.5 & 205.6 & $17.3 \pm 28.4$ & 3.3 & 108.4 \\
\hline DIN:P-SRP * & $37 \pm 44$ & 2 & 143 & $244 \pm 256$ & 21 & 832 \\
\hline Chl-a $\left(\mu \mathrm{g} \mathrm{L}^{-1}\right)$ & $1.7 \pm 1.6$ & 0.2 & 5.1 & $0.6 \pm 0.35$ & 0.29 & 1.1 \\
\hline
\end{tabular}




\subsection{Field Sampling}

Water samples for phytoplankton analyses were collected monthly over a full year (March 2000 to March 2001). Analyses were completed at the time, but the preparation of the material for publication was not possible until now. Hence, these valuable historical data represent an important baseline for further studies. Samples were retrieved from the central area of both lakes (average depth: El Sol $12.7 \pm 0.4 \mathrm{~m}$, La Luna $10.2 \pm 0.4 \mathrm{~m}$ ) at three water depths: surface ( $1 \mathrm{~m}$ below surface), mid water column, and bottom (1 m above sediment) using a Niskin or Van Dorn bottle. Samples for identification were kept refrigerated, and samples for counting were fixed with $1 \%$ Lugol's acetic iodine solution.

\subsection{Laboratory Analysis}

The identifications were made by first examining in vivo samples and further on material preserved at low temperature. These samples were analyzed using a Carl Zeiss phasecontrast microscope at $400-1000 \times$. Bacillariophyceae were cleaned with hydrogen peroxide following standard procedures [34]. Selected diatom samples were prepared and observed with a scanning electron microscope (JEOL JSM-5300) to confirm identification. Identification was based on the following literature: Comas [35], Desikachary [36], Dillar [37-40], Ettl \& Gärtner [41], Huber-Pestalozzi [42-44], Komárek and Anagnostidis [45], Komárek and Fott [46], Krammer and Langer-Bertalot [47-50], Philipose [51], Popovský and Pfiester [52], and Prescott et al. [53-55]. Phytoplankton taxonomy was according to AlgaeBase [56].

Cell counts were done by the Utermhöl method [57] with a Carl Zeiss D inverted microscope using 50- and 100-mL sedimentation chambers. The three water depths turned out to be similar and treated as replicates. The density values (cells $\mathrm{mL}^{-1}$ ) were multiplied by the biovolume of each species using geometric formulas related to the shape of the cell [58]. A minimum of 15 measurements were made for each species, from which the average biovolume value was obtained. Biovolume values are reported as $\mathrm{mm}^{3} \mathrm{~m}^{-3}$.

Identified taxa were appointed either as phytoplankton or tychoplankton. Tychoplankton is a common term applied to non-planktonic organisms, such as free-living or attached benthic organisms, that are carried into the plankton through a disturbance of their benthic habitat, or by winds and currents [59,60] (Diatoms of North America Glossary at https:/ / diatoms.org/glossary/tycoplanktonic; accessed on 6 January 2022).

The phytoplankton species richness was determined as the total number of species recorded during the counts. The Shannon-Wiener diversity index was calculated using the Primer Program 6.1.6.3.

\subsection{Statistical Analysis}

Multiple variance analysis (MANOVA) was performed using STATISTICA V12.4 64 Bits, to determine if there were significant differences between both lakes. ANOVA was performed to identify significant differences in environmental (listed in Table 1) and biological variables (species richness, diversity, density, and biomass) between both lakes. The data were transformed to a base 10 logarithm to eliminate bias or external variability, except for $\mathrm{pH}$. The confidence level was $\alpha<0.05$.

Bivariate diagrams of abundance $[\log n+1]$ versus frequency of occurrence, also known as the Olmstead-Tukey diagram [61], were used. The diagram classifies the taxa into four categories: representative/dominant (high abundance and frequency), abundant/temporal (high abundance, low frequency), constant/frequent (low abundance, high frequency), and rare (low abundance, low frequency). The discrimination criterion is based on the mean of the relative frequency of appearance for the " $\mathrm{X}$ " axis and the respective mean of the natural logarithm of the sum of the relative abundance for the " $Y$ " axis.

\section{Results}

As mentioned before, although both lakes are only $600 \mathrm{~m}$ apart and they share a common origin, climate, and water regime, Lakes El Sol and La Luna display differences in their physical and chemical characteristics. Lake El Sol is larger and deeper than Lake 
La Luna; it has benthic vegetation (Chara) covering wide expanses of the littoral zone, and it currently holds a fish (rainbow trout) population. In addition, there are significant differences $(\alpha<0.05)$ between both lakes in terms of water transparency, nitrogen and silica concentrations, $\mathrm{pH}$, and electrical conductivity (Table 1 ).

The phytoplankton species richness found in Lakes El Sol and La Luna included 92 taxa of which 47 were identified to species [51\%] and 45 [49\%] were identified as morphospecies [Table 2].

Table 2. Phytoplankton taxonomic list of HML El Sol and La Luna, Nevado de Toluca. According to AlgaeBase [42]. (X indicates the species presence. ${ }^{*}$ Indicates tychoplanktonic morphospecies). (Navicula NTA and N. NTB according to [15]).

\begin{tabular}{|c|c|c|}
\hline Taxa & El Sol & La Luna \\
\hline \multicolumn{3}{|l|}{ Phylum: Cyanobacteria } \\
\hline \multicolumn{3}{|l|}{ Class: Cyanophyceae } \\
\hline \multicolumn{3}{|l|}{ Order: Chroococcales } \\
\hline \multirow{2}{*}{\multicolumn{3}{|c|}{$\begin{array}{l}\text { Limnococcus limneticus [Lemmerman] Komárkova, Jezbarová, Komárek } \\
\text { \& Zapomelová }\end{array}$}} \\
\hline & & \\
\hline \multirow{2}{*}{$\begin{array}{l}\text { Anabaena cf. lapponica Borge } \\
\text { Anabaena sp. }\end{array}$} & $\mathrm{x}$ & \\
\hline & $\mathrm{x}$ & \\
\hline \multicolumn{3}{|l|}{ Order: Oscillatoriales } \\
\hline \multirow{2}{*}{\multicolumn{3}{|c|}{$\begin{array}{l}\text { Limnoraphis birgei [Smith] Komárek, Zapomelová, Smarda, Kopecký. } \\
\text { Rejimánková, Woodhouse, Neilan \& Komárková }\end{array}$}} \\
\hline & & \\
\hline \multicolumn{3}{|l|}{ Order: Synechococcales } \\
\hline Merismopedia sp. & $\mathrm{X}$ & \\
\hline Synechocystis minuscula Woronichin & $\mathrm{x}$ & \\
\hline Synechocystis sp. & $\mathrm{x}$ & $\mathrm{x}$ \\
\hline Pseudoanabaena sp. & $\mathrm{x}$ & \\
\hline \multicolumn{3}{|l|}{ Phylum: Ochrophyta } \\
\hline \multicolumn{3}{|l|}{ Class: Chrysophyceae } \\
\hline \multicolumn{3}{|l|}{ Order: Chromulinales } \\
\hline Chromulina sp. & $\mathrm{x}$ & $\mathrm{x}$ \\
\hline Chrysococcus minutus [Fritsch] Nygaard & $\mathrm{X}$ & \\
\hline Dinobryon cf. sociale [Ehrenberg] Ehrenberg & $\mathrm{x}$ & \\
\hline Ochromonas sp. & $\mathrm{x}$ & $\mathrm{X}$ \\
\hline \multirow{2}{*}{\multicolumn{3}{|c|}{$\begin{array}{l}\text { Class: Synurophyceae } \\
\text { Order: Synurales }\end{array}$}} \\
\hline & & \\
\hline Mallomonas cf. acaroides Perty & $\mathrm{x}$ & \\
\hline Mallomonas sp. 1 & $\mathrm{x}$ & $\mathrm{x}$ \\
\hline Mallomonas sp. 2 & $\mathrm{x}$ & \\
\hline \multicolumn{3}{|l|}{ Phylum: Bacillariophyta } \\
\hline \multicolumn{3}{|l|}{ Class: Coscinodiscophyceae } \\
\hline \multicolumn{3}{|l|}{ Order: Aulacoseirales } \\
\hline Aulacoseira nivaloides [Cambrun] English \& Potatova & $\mathrm{X}$ & $\mathrm{X}$ \\
\hline Aulacoseira cf. alpigena [Grunow] Krammer & $\mathrm{X}$ & $\mathrm{x}$ \\
\hline \multicolumn{3}{|l|}{ Class: Mediophyceae } \\
\hline \multicolumn{3}{|l|}{ Order: Stephanodiscales } \\
\hline Cyclotella aff. quillensis Bailey & $\mathrm{x}$ & $\mathrm{x}$ \\
\hline Cyclotella sp. & $\mathrm{x}$ & $\mathrm{x}$ \\
\hline \multirow{2}{*}{\multicolumn{3}{|c|}{$\begin{array}{l}\text { Class: Bacillaripophyceae } \\
\text { Order: Bacillariales }\end{array}$}} \\
\hline & & \\
\hline Nitzschia cf. acidoclinata Lange-Bertalot* & $\mathrm{x}$ & $\mathrm{X}$ \\
\hline Nitzschia sp. * & $\mathrm{x}$ & $\mathrm{X}$ \\
\hline Order: Cocconeidales & & \\
\hline Achnanthidium minutissimum [Kützing] Czarnecki * & $\mathrm{x}$ & \\
\hline Psammothidium helveticum [Hustedt] Bukhtiyarova \& Round * & $\mathrm{x}$ & $\mathrm{x}$ \\
\hline Psammothidium levanderi [Hustedt] Bukhtiyarova \& Round * & $\mathrm{x}$ & $\mathrm{X}$ \\
\hline
\end{tabular}


Table 2. Cont.

\begin{tabular}{|c|c|c|}
\hline Taxa & El Sol & La Luna \\
\hline \multicolumn{3}{|l|}{ Order: Cymbellales } \\
\hline Encyonema gracile Rabenhorst * & $X$ & \\
\hline Encyonema perpusillum [Cleve-Euler] Mann * & $X$ & $X$ \\
\hline Gomphonema angustatum [Kützing] Rabenhorst * & $X$ & $X$ \\
\hline \multicolumn{3}{|l|}{ Order: Fragilariales } \\
\hline Staurosira aff. venter [Ehrenberg] Cleve \& Möller* & $X$ & $X$ \\
\hline Staurosira pseudoconstruens [Marciniak] Lange-Bertalot * & $X$ & $X$ \\
\hline Staurosirella pinnata [Ehrenberg] Williams \& Round * & $X$ & $X$ \\
\hline \multicolumn{3}{|l|}{ Order: Naviculales } \\
\hline Brachysira sp. * & $x$ & $x$ \\
\hline Cavinula pseudocutiformis [Hustedt] Man \& Stickle * & $x$ & $x$ \\
\hline Frustulia rhomboides [Ehrenberg] De Toni * & $X$ & $X$ \\
\hline Navicula NTA * & $x$ & $x$ \\
\hline Navicula NTB* & $x$ & \\
\hline Pinnularia microstauron [Ehrenberg] Cleve * & $x$ & $x$ \\
\hline Pinnularia cf. viridis [Nitzsch] Ehrenberg * & $X$ & $x$ \\
\hline Pinnularia subcapitata W. Gregory * & $X$ & $X$ \\
\hline Pinnularia sp. 1 * & $x$ & \\
\hline Pinnularia sp. $2 *$ & $x$ & $x$ \\
\hline Sellaphora sp. * & $x$ & \\
\hline Stauroneis anceps Ehrenberg * & $X$ & $X$ \\
\hline \multicolumn{3}{|l|}{ Order: Surirellales } \\
\hline Stenopterobia sp. 1 * & $X$ & $X$ \\
\hline Stenopterobia sp. $2 *$ & $x$ & $x$ \\
\hline Surirella cf. linearis Smith * & $x$ & $x$ \\
\hline Surirella cf. angusta Kützing * & $X$ & $X$ \\
\hline Surirella sp. * & $x$ & $x$ \\
\hline \multicolumn{3}{|l|}{ Phylum: Haptophyta } \\
\hline \multicolumn{3}{|l|}{ Class: Coccolithophyceae } \\
\hline \multicolumn{3}{|l|}{ Order: Prymnesiales } \\
\hline Chrysochromulina aff. parva Lackey & $x$ & $x$ \\
\hline \multicolumn{3}{|l|}{ Phylum: Cryptophyta } \\
\hline \multicolumn{3}{|l|}{ Class: Cryptophyceae } \\
\hline \multicolumn{3}{|l|}{ Order: Cryptomonadales } \\
\hline Chroomonas nordstedt Hansgirg & $X$ & \\
\hline Chroomonas sp. & $x$ & $x$ \\
\hline Cryptomonas sp. 1 & $x$ & $x$ \\
\hline Cryptomonas sp. 2 & $x$ & $x$ \\
\hline \multicolumn{3}{|l|}{ Phylum: Miozoa } \\
\hline \multicolumn{3}{|l|}{ Class: Dinophyceae } \\
\hline \multicolumn{3}{|l|}{ Order: Gymnodiniales } \\
\hline Gymnodinum sp. & $x$ & $x$ \\
\hline \multicolumn{3}{|l|}{ Order: Peridiniales } \\
\hline Parvodinium umbonatum [Stein] Carty & $x$ & $X$ \\
\hline Peridinium cf. volzii Lemmermann & $x$ & \\
\hline Peridinium willei Huitfeldt-Kaas & $x$ & $x$ \\
\hline \multicolumn{3}{|l|}{ Phylum Euglenozoa } \\
\hline \multicolumn{3}{|l|}{ Class: Euglenophyceae } \\
\hline \multicolumn{3}{|l|}{ Order: Euglenales } \\
\hline Euglena sp. & $x$ & \\
\hline Lepocinclis sp. & $x$ & \\
\hline Trachelomonas sp. 1 & $x$ & \\
\hline Trachelomonas sp. 2 & $x$ & \\
\hline \multicolumn{3}{|l|}{ Phylum: Chlorophyta } \\
\hline Class: Chlorophyceae & & \\
\hline Order: Chlamydomonadales & & \\
\hline Chlamydomonas sp. 1 & $x$ & $x$ \\
\hline Chlamydomonas sp. 2 & $X$ & $X$ \\
\hline Carteria sp. & $X$ & $x$ \\
\hline
\end{tabular}


Table 2. Cont.

\begin{tabular}{|c|c|c|}
\hline Taxa & El Sol & La Luna \\
\hline Gemellicystis planctonica [Woronichin] Lund & $x$ & $x$ \\
\hline Microglena sp. & $X$ & \\
\hline Palmella sp. & $X$ & $X$ \\
\hline Sphaerocystis schroeteri Chodat & $x$ & $x$ \\
\hline \multicolumn{3}{|l|}{ Order: Chlorellales } \\
\hline Oocystis lacustris Chodat & $x$ & $x$ \\
\hline Oocystis sp. & $X$ & $X$ \\
\hline \multicolumn{3}{|l|}{ Order: Oedogoniales } \\
\hline Oedogonium sp. & $x$ & $x$ \\
\hline \multicolumn{3}{|l|}{ Order: Sphaeropleales } \\
\hline Ankistrodesmus sp. & $x$ & \\
\hline Coelastrum sp. & $x$ & \\
\hline Desmodesmus abundans [Kirchner] Hegewald & $X$ & $x$ \\
\hline Desmodesmus spinosus [Chodat] Hegewa & $x$ & \\
\hline Gloeocystis sp. & $x$ & \\
\hline Monoraphidium minutum [Nägeli] Komárková-Legnerová & $X$ & \\
\hline Monoraphidium obtusum [Korshikov] Komárková-Legnerová & $x$ & $x$ \\
\hline Tetradesmus obliquus [Turpin] Wynne & $x$ & \\
\hline \multicolumn{3}{|l|}{ Order:Trebouxiales } \\
\hline Botryococcus braunii Kützing & $X$ & $x$ \\
\hline \multicolumn{3}{|l|}{ Phylum: Charophyta } \\
\hline \multicolumn{3}{|l|}{ Class: Charophyceae } \\
\hline \multicolumn{3}{|l|}{ Order: Charales } \\
\hline Nitella sp. & $X$ & \\
\hline \multicolumn{3}{|l|}{ Class: Coleochaetophyceae } \\
\hline \multicolumn{3}{|l|}{ Order: Chaetosphaeridiales } \\
\hline Chaetosphaeridium globosum [Nordstedt] Klebahn & $x$ & $x$ \\
\hline \multicolumn{3}{|l|}{ Class: Conjugatophyceae } \\
\hline \multicolumn{3}{|l|}{ Order: Desmidiales } \\
\hline Cosmarium cf. exiguum Archer & $X$ & $\mathrm{X}$ \\
\hline Closterium lunula Ehrenberg \& Hemprich ex Ralfs & $x$ & $x$ \\
\hline Closterium sp. & $x$ & $x$ \\
\hline Desmidium sp. & $x$ & $x$ \\
\hline Euastrum cf. oblongum Ralfs & $X$ & $X$ \\
\hline Micrasterias radiosa Ralfs & $x$ & $x$ \\
\hline Staurastrum sp. & $x$ & $x$ \\
\hline \multicolumn{3}{|l|}{ Order: Zygnematales } \\
\hline Temnogametum iztacalense Garduño \& Martínez & $x$ & $x$ \\
\hline Spirogyra sp. & $x$ & \\
\hline Zygnema sp. & $x$ & $X$ \\
\hline Total & 92 & 63 \\
\hline
\end{tabular}

All 92 taxa were present in Lake El Sol, but only $63(\approx 68 \%)$ were in Lake La Luna (Table 2). The most diverse algal groups were Bacillariophyceae (El Sol 34.8\%, La Luna $42.9 \%$ ) and Chlorophyceae (El Sol 20.6\%, La Luna 19\%), accounting for $>50 \%$ of the species richness in both lakes. The species richness (S) in Lake El Sol averaged $32 \pm 6.7$ (15-41), while in Lake Luna, it averaged $19 \pm 4.2$ (10-25). S in Lake El Sol was significantly higher $(\alpha<0.05)$ than in Lake La Luna. The average value of the Shannon-Wiener index in Lake El Sol averaged $2.8 \pm 0.6$ (1.6-3.7), while in Lake La Luna, it averaged $2.4 \pm 0.5$ (1.1-2.9).

According to the Olmstead-Tukey diagrams, there were 21 (out of $92, \approx 23 \%$ ) species with high abundance and frequency in Lake El Sol and 17 species (out of $63, \approx 27 \%$ ) in Lake La Luna (Figure 2, Table 3). Both lakes shared 9 of these species (31\%), while 12 were of high abundance and frequency [57.1\%] exclusively in Lake El Sol, and 8 [47.1\%] exclusively in Lake La Luna. 


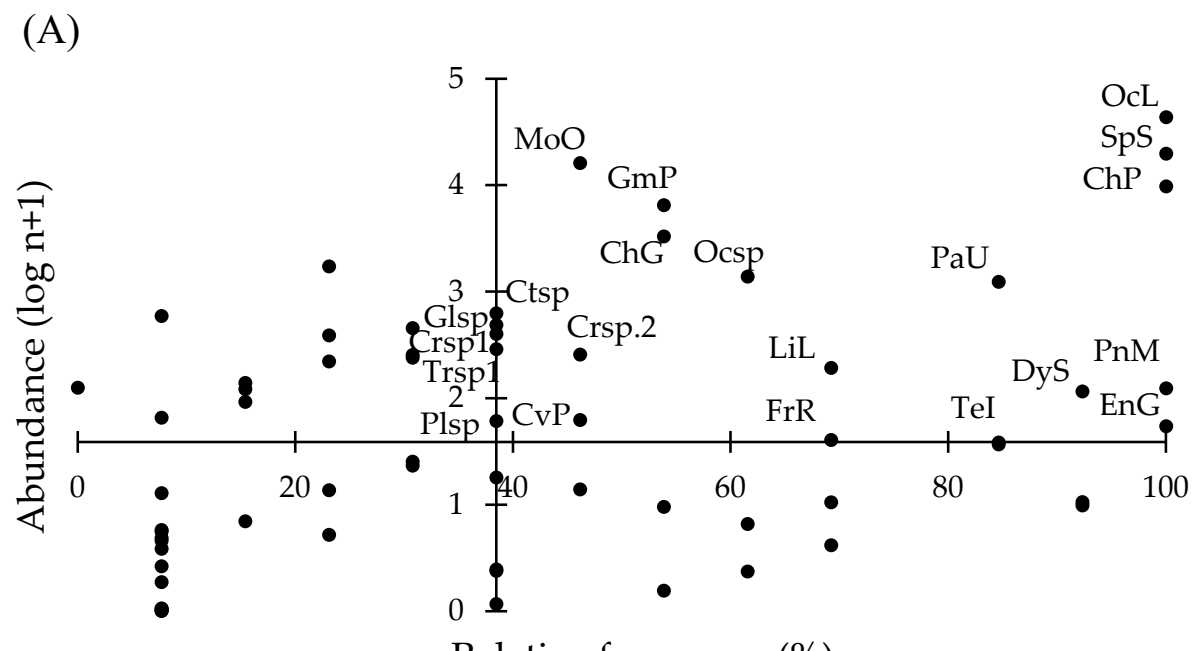

(B)

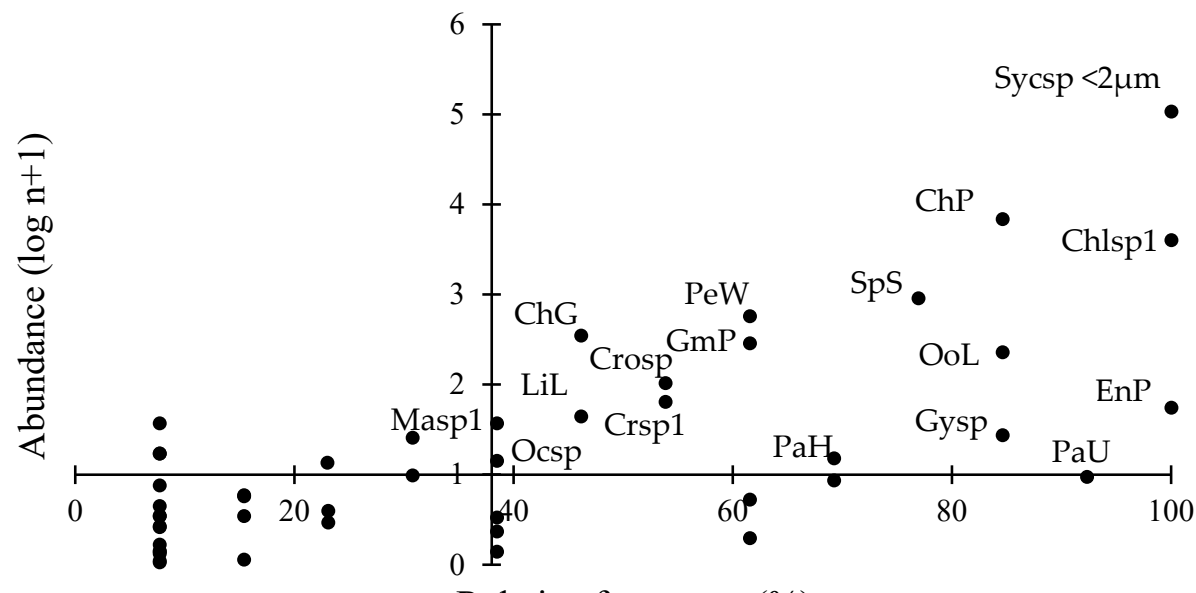

Relative frequency (\%)

Figure 2. Bivariate [Olmstead-Tukey] diagrams of abundance $(\log n+1)$ versus relative frequency (\%) of the phytoplankton of Lakes (A) El Sol and (B) La Luna. (See species keys in Table 3).

In the Olmstead-Tukey diagrams of both lakes, tycoplanktonic and truly planktonic forms were included among the representative (large abundance and high frequency of occurrence) taxa. The tychoplanktonic forms were Bacillariophyceae (Cavinula pseudocutiformis, Pinnularia microstauron, Encyonema gracile, Frustulia rhomboides, Encyonema perpusillum, Psamotidium helveticum), Coleochaetophyceae (Chaetosphaeridium globosum), and Chrysophyceae (Dinobryon cf. sociale). The truly planktonic forms were Chlorophyceae with pods (e.g., Oocystis lacustris, Sphaerocystis schroeteri, Gemellicystis planctonica, Gloeocystis sp. Monoraphidium obtusum), which gives buoyancy and grazing protection, and the podless Synechocystis sp. in Lake La Luna. Representative species of Dinophyceae, Chrysophyceae, Synurophyceae, Chlorophyceae, Cryptophyceae, and Euglenophyceae have flagellum (e.g., Chrysochromulina aff. parva, Parvodinium umbonatum, Peridinium willei, Gimnodinium sp., Trachelomonas sp. 1, Carteria sp., Chlamydomonas sp. 1), which can move freely to seek food and protection.

Phytoplankton density in Lake El Sol averaged 17,383 $\pm 16,650$ cells $\mathrm{mL}^{-1}$ (2556-149,455 cells $\mathrm{mL}^{-1}$ ), while in Lake La Luna the phytoplankton density averaged $9361 \pm 5355$ cells $\mathrm{mL}^{-1}\left(188-25,499\right.$ cells $\left.\mathrm{mL}^{-1}\right)$. The density in Lake El Sol was significantly higher $(\alpha<0.05)$ than in Lake La Luna. According to their contribution to the global abundance, the chlorophyte Oocystis lacustris (58.2\%) was the dominant species in Lake El Sol, followed by Sphaerocystis schroeteri, Monoraphidium obtusum, Chrysochromulina aff. parva, and Gemellicystis planctonica. The other 87 species contributed less than 1\%. In Lake 
La Luna, the dominant species was the Cyanobacteria Synechocystis sp. (89\%), followed by Chrysochromulina aff. parva, and Chlamydomona sp. 1 . The other 60 species contributed less than 1\% (Table 4). The phytoplankton density data are provided in Supplementary Information Table S1.

Table 3. Representative species (large abundance and high frequency of occurrence) in Lakes El Sol and La Luna.

\begin{tabular}{|c|c|}
\hline Lake El Sol & Lake La Luna \\
\hline \multicolumn{2}{|c|}{ Chaetosphaeridium globosum [ChG] } \\
\hline \multicolumn{2}{|c|}{ Chryptomonas sp. 1 [Crsp1] } \\
\hline \multicolumn{2}{|c|}{ Chrysochromulina aff. parva [ChP] } \\
\hline \multicolumn{2}{|c|}{ Gemellicystis planctonica $[\mathrm{GmP}]$} \\
\hline \multicolumn{2}{|c|}{ Limnococcus limneticus [LiL] } \\
\hline \multicolumn{2}{|c|}{ Ochromonas sp [Ocsp] } \\
\hline \multicolumn{2}{|c|}{ Oocystis lacustris [OcL] } \\
\hline \multicolumn{2}{|c|}{ Parvodinium umbonatum [PaU] } \\
\hline \multicolumn{2}{|c|}{ Sphaerocystis schroeteri [SpS] } \\
\hline Chryptomonas sp. 2 [Crsp2] & Chlamydomonas sp. 1 [Chsp1] \\
\hline Cavinula pseudocutiformis [CvP] & Chroomonas sp. [Crosp] \\
\hline Dynobryon cf. sociale [DyS] & Encyonema perpusillum [EnP) \\
\hline Encyonema gracile [EnG] & Gymnodinum sp. [Gysp] \\
\hline Frustulia rhomboides [FrR] & Mallomonas sp. 1 [Masp1] \\
\hline Gloeocystis sp. [Glsp] & Peridinium willei $[\mathrm{PeW}]$ \\
\hline Monoraphidium obtusum [MoO] & Psammothidium helveticum $[\mathrm{PaH}]$ \\
\hline Palmella sp. [Plsp] & Synechocystis sp. $<2 \mu \mathrm{m}$ [Sycsp] \\
\hline \multicolumn{2}{|l|}{ Carteria sp. [Ctsp] } \\
\hline \multicolumn{2}{|l|}{ Pinnularia microstauron [PnM] } \\
\hline \multicolumn{2}{|l|}{ Temnogametum iztacalense [TeI] } \\
\hline Trachelomonas sp. 1 [Trsp1] & \\
\hline
\end{tabular}

Table 4. Dominant species in abundance (>1\%) and biomass (>10\%) in Lakes El Sol and La Luna.

\begin{tabular}{lclc}
\hline \multicolumn{1}{c}{ Lake El Sol } & \multicolumn{2}{c}{ La Luna } \\
\hline \multicolumn{1}{c}{ Abundance } & $\%$ & \multicolumn{1}{c}{ Abundance } & $\%$ \\
\hline Oocystis lacustris & 58.2 & Synechocystis sp. & 89.1 \\
Sphaerocystis schroeteri & 17.9 & Chrysochromulina aff. parva & 5.8 \\
Monoraphidium obtusum & 8.7 & Chlamydomonas sp. 1 & 3.3 \\
Chrysochromulina aff. parva & 7.5 & & \\
Gemellicystis planctonica & 5.9 & \multicolumn{1}{c}{ Biomass } \\
$\quad$ Biomass & $\%$ & Gymnodinum sp. & $\%$ \\
\hline Monoraphidium obtusum & 19.0 & Parvodinium umbonatum & 17.5 \\
Sphaerocystis schroeteri & 14.5 & Synechocystis sp. & 14.2 \\
Oocystis lacustris & 10.6 & Encyonema perpusillum & 14.7 \\
& & Peridinium willei & 14.6 \\
\hline
\end{tabular}

Phytoplankton biomass (biovolume) in Lake El Sol averaged 1,074,505 $\pm 688,770 \mathrm{~mm}^{3} \mathrm{~m}^{-3}$ $\left(174,952-2,814,852 \mathrm{~mm}^{3} \mathrm{~m}^{-3}\right)$, while in Lake La Luna, the phytoplankton biomass averaged $155,607 \pm 144,026 \mathrm{~mm}^{3} \mathrm{~m}^{-3}\left(6640-630,982 \mathrm{~mm}^{3} \mathrm{~m}^{-3}\right)$. Biomass in Lake El Sol was significantly higher $(\alpha<0.05)$ than in Lake La Luna. Regarding the global biomass, the Chlorophytes Monoraphidium obtusum, Sphaerocystis schroeteri, and Oocystis lacustris had a higher contribution in Lake El Sol. The other 89 species contributed less than 10\%. In Lake La Luna the higher biomass contribution was by the dinoflagellates Gymnodinum sp., Parvodinium umbonatum, and Peridinium willei, followed by the Cyanobacteria Synechocystis sp., and the tycoplanktonic diatom Encyonema perpusillum. The other 58 species contributed less than $10 \%$ (Table 4 ). The phytoplankton biomass (biovolume) data are provided in Supplementary Information Table S1. 


\section{Discussion}

Phytoplankton diversity from Mexican inland waters is estimated to be close to 1025 to 1100 species $[62,63]$. Taking this value as a reference, the total phytoplankton diversity found in the Nevado de Toluca HML lakes represents around 10\% of the global phytoplankton richness reported for Mexican inland waters. Nonetheless, it must be noted that there is evidence of hidden phytoplankton diversity in these lakes, as indicated by the presence of a diverse Chrysophyte stomatocyst assemblage in the lake sediments [64], which is not reflected in the Chrysophyte [Synurales] diversity in this study, where only 3 morphotypes were identified. Relatively high values of the Shannon-Wiener diversity index, such as those recorded in Lakes El Sol and La Luna, are characteristic of unstable/astatic lakes; lower diversities are expected in stable lakes where the species are adapted and favor competitive exclusion, leading to the dominance of a few species [65].

The 45 morphospecies were morphologically clearly identified as different species; however, it was not possible to find a correct match for them in the available literature. This was the case, for example, for two diatom species previously reported for these lakes by Caballero [29] as Navicula NTA and Navicula NTB, which are new and possibly endemic taxa. Therefore, in this study, it is also very likely that at least some of the morphospecies are new to science, yet to be described, as exemplified with Temnogametum iztacalense Garduño \& Martínez, a new species of Zygnemataceae recently described [66], and previously reported as Mougeotia. A comparable situation is repeated in other biological groups studied in this lake, as zooplankton investigations on Lakes El Sol and Luna revealed the presence of numerous new and very likely endemic species, e.g., $[24,25,67,68]$; so, it is not surprising to find new phytoplankton species in this study. Finally, it must be remembered that, in tropical inland waters, phytoplankton species composition is by far less known than their temperate counterparts, and therefore they are sub-represented in taxonomic keys.

However, for a better understanding of phytoplankton diversity in HML, it is important to consider that several tychoplanktonic taxa can be included in phytoplankton samples given that most HML are shallow and wind turbulence can mix the whole water column. In this regard, other variables have been similar, and a larger contribution of tychoplankton to tropical HML should be expected, since wind driven turbulence is present along the annual cycle given that tropical HML have no winter ice cover, which is a common feature in temperate HML [69] that limits resuspension for several months. This was clearly the case among the Bacillariophyceae in the Nevado de Toluca lakes, as tychoplanktonic taxa were the majority ( 28 taxa, $87.5 \%$ ), with only 4 truly planktonic taxa $(12.5 \%)$.

On the other hand, the phytoplankton species richness reported for HML outside Mexico was lower than in the Nevado de Toluca lakes, particularly those from the temperate region (Table 5). The highest species richness reported is 50 species found in $16 \mathrm{HML}$ from the Adamello-Brenta Regional Park (46 ${ }^{\circ}$ N, 1936-2663 m a.s.l.), Italy [9]. However, this number must certainly correspond to a lower species richness per site, considering that it corresponds to an analysis of 16 lakes, while in the Nevado de Toluca the 92 taxa were present in a single lake (El Sol). It must be noted that the phytoplankton species lists reported from other HML worldwide also include tychoplankton, so they are comparable with Lakes El Sol and La Luna. 
Table 5. Phytoplankton taxonomic richness (S), and percent (\%) contribution per phytoplankton group in tropical ${ }^{*}$ ) and temperate HML. (a: diatoms not included, b: includes epilithic diatoms). (Number of water bodies included in the study are below name). (Mex1: Mexico [63]; Mex2: Mexico [70]; Sol: Lake El Sol; Luna: Lake La Luna; ZL: Zempoala lakes, México [71]; SP: Lake San Pablo, Ecuador [19]; CR: Colombian reservoirs [72]; KL: Lake Kolsay, Kazakhstan [73]; LI: Laghetto Inferiore, Switzerland [74]; AL: Adamello-Brenta lakes, Italy [9]; TML: Tatra Mountains lakes, Slovakia [75]).

\begin{tabular}{|c|c|c|c|c|c|c|c|c|c|c|c|}
\hline \multirow{2}{*}{ Phytoplankton Phylum (Class) } & Mex1 & Mex2 & Sol * & Luna * & $Z^{a *}$ & $\mathrm{SP} *$ & $\mathbf{C R} *$ & KL & LI & $\mathrm{AL}^{\mathrm{b}}$ & TML \\
\hline & 55 & 56 & 1 & 1 & 5 & 1 & 4 & 4 & 1 & 16 & 3 \\
\hline \multirow{2}{*}{ Cyanobacteria (Cyanophyceae) } & 187 & 65 & 9 & 3 & 12 & 1 & 6 & 3 & 2 & 1 & 1 \\
\hline & $18 \%$ & $10 \%$ & $10 \%$ & $5 \%$ & $22 \%$ & $4 \%$ & $6 \%$ & $11 \%$ & $6 \%$ & $1 \%$ & $2 \%$ \\
\hline \multirow{2}{*}{$\begin{array}{l}\text { Ochrophyta (Chrysophyceae and } \\
\text { Synurophyceae) }\end{array}$} & 37 & 10 & 7 & 3 & 2 & 0 & 2 & 0 & 4 & 16 & 11 \\
\hline & $4 \%$ & $1 \%$ & $8 \%$ & $5 \%$ & $4 \%$ & $0 \%$ & $2 \%$ & $0 \%$ & $11 \%$ & $20 \%$ & $27 \%$ \\
\hline \multirow{3}{*}{$\begin{array}{c}\text { Bacillariophyta (Coscinodiscophycea, } \\
\text { Mediophyceae, and Bacillariophyceae) } \\
\text { Haptophyta }\end{array}$} & 327 & 262 & 32 & 27 & - & 5 & 15 & 15 & 4 & 32 & 6 \\
\hline & $32 \%$ & $40 \%$ & $35 \%$ & $43 \%$ & - & $18 \%$ & $16 \%$ & $54 \%$ & $11 \%$ & $40 \%$ & $15 \%$ \\
\hline & 0 & 0 & 1 & 1 & 0 & 0 & 0 & 0 & 0 & 0 & 0 \\
\hline $\begin{array}{l}\text { Haptophyta } \\
\text { (Coccolitophyceae) }\end{array}$ & $0 \%$ & $0 \%$ & $1 \%$ & $2 \%$ & $0 \%$ & $0 \%$ & $0 \%$ & $0 \%$ & $0 \%$ & $0 \%$ & $0 \%$ \\
\hline \multirow{2}{*}{ Cryptophyta (Cryptophyceae) } & 8 & 2 & 4 & 3 & 1 & 3 & 1 & 0 & 5 & 7 & 2 \\
\hline & $1 \%$ & $(<1 \%)$ & $4 \%$ & $5 \%$ & $2 \%$ & $11 \%$ & $1 \%$ & $0 \%$ & $14 \%$ & $9 \%$ & $5 \%$ \\
\hline \multirow{2}{*}{$\begin{array}{c}\text { Miozoa } \\
\text { (Dinophyceae) }\end{array}$} & 28 & 6 & 4 & 3 & 2 & 2 & 3 & 0 & 5 & 7 & 6 \\
\hline & $3 \%$ & $1 \%$ & $4 \%$ & $5 \%$ & $4 \%$ & $7 \%$ & $3 \%$ & $0 \%$ & $14 \%$ & $9 \%$ & $15 \%$ \\
\hline \multirow{2}{*}{ Euglenozoa (Euglenophyceae) } & 95 & 13 & 4 & 0 & 7 & 2 & 9 & 2 & 0 & 0 & 1 \\
\hline & $9 \%$ & $2 \%$ & $4 \%$ & $0 \%$ & $13 \%$ & $7 \%$ & $9 \%$ & $7 \%$ & $0 \%$ & $0 \%$ & $2 \%$ \\
\hline \multirow{2}{*}{ Chorophyta (Chlorophyceae) } & 233 & 307 & 19 & 12 & 21 & 13 & 37 & 7 & 8 & 6 & 10 \\
\hline & $23 \%$ & $46 \%$ & $21 \%$ & $19 \%$ & $38 \%$ & $48 \%$ & $38 \%$ & $25 \%$ & $23 \%$ & $7 \%$ & $25 \%$ \\
\hline \multirow{2}{*}{$\begin{array}{c}\text { Charophyta (Charophyceae, } \\
\text { Coleochaetophyceae, and Conjugatophyceae) }\end{array}$} & 108 & - & 12 & 11 & 8 & 1 & 23 & 1 & 6 & 10 & 3 \\
\hline & $10 \%$ & - & $13 \%$ & $17 \%$ & $15 \%$ & $4 \%$ & $24 \%$ & $4 \%$ & $17 \%$ & $12 \%$ & $7 \%$ \\
\hline $\begin{array}{c}\text { Total } \\
\text { (Richness per lake) }\end{array}$ & $\begin{array}{l}1025 \\
(>200)\end{array}$ & 668 & 92 & 63 & $\begin{array}{c}55 \\
(1-40)\end{array}$ & 27 & $\begin{array}{c}96 \\
(6-49)\end{array}$ & $\begin{array}{c}28 \\
(6-15)\end{array}$ & 35 & 79 & 40 \\
\hline
\end{tabular}

Increasing species diversity from the poles towards the tropics or the LDG (latitudinal diversity gradient) has been long postulated in terrestrial and marine ecosystems (e.g., [76]). However, the mechanisms behind this trend are still far from being understood, representing one of the significant contemporary biogeography challenges (e.g., [77]). The reduced climatic variation in areas close to the Equator favors tropical species to develop small thermal tolerance ranges and a restricted dispersion. These features, especially in mountainous environments (e.g., HML), generate rapid isolation between populations and develop new species [78]. Nevertheless, there is no evidence directly connecting ecological process gradients within communities at a local scale to the geographic gradient in biodiversity [79].

Regarding composition, Bacillariophyceae is the most diversified phytoplankton group in Mexico [80]; Oliva-Martínez et al. [63] report that Bacillariophyceae constitutes 31.9\% of the total phytoplankton taxonomic richness, while Garduño Solórzano et al. [70] report they represent $40.6 \%$, second only to Chlorophyta (46.3\%); in accordance, it was also the most diverse group in the Nevado de Toluca lakes (34.8\% in Lake El Sol and $42.9 \%$ in Lake La Luna). Cyanophyceae ranked second in Oliva-Martínez et al. [63], and third in Garduño Solórzano [70] (18.2\% and 9.8\%, respectively); however, they graded fourth in both Lake El Sol (9.8\%) and Lake La Luna (4.8\%), after Bacillariophyceae, Chlorophyceae, and Conjugatophyceae (Zygnematophyceae). According to Rivera et al. [81], a rich Desmidiales (Conjugatophyceae) assemblage is a feature distinctive of many tropical HML; but in Lakes El Sol and La Luna, this is not the case, as there were only seven taxa $(\approx 8 \%$ of the total community), all of which were present in both lakes.

Löffler [15], 1972 provides the first report of the phytoplankton composition of the Nevado de Toluca lakes with Peridinium willei, P. volzii, Botryococcus braunii, and Dinobryon. We found all these taxa in El Sol, but only P. willei and B. braunii in La Luna. The motility of Dinophyceae, in this case $P$. willei, along with a facultative mixotrophic behavior (feeding on, for example, Synechocystis sp.), allowed this species to be successful in the ultraoligotrophic waters of Lake La Luna [82].

In research on trophic relationships in HML, the importance of mixotrophy has been emphasized, a characteristic of nanoplankton flagellates $(<20 \mu \mathrm{m})$ (Dinophyceae, Chryso- 
phyceae, Cryptophyceae, Chlorophyceae flagellates). These taxa represent the dominant fraction $(>50 \%)$ of the phytoplankton of oligotrophic HML, particularly in lakes that lack fish [83]. Without the majority contribution of Synechocystis sp. in abundance in Lake La Luna, the dominant taxa are the mixotrophic flagellates, which feed on picophytoplankton $(<2$, Synechocystis sp.) or can absorb dissolved matter from the water column in nutrient-poor lakes, such as Lake La Luna [84].

As mentioned, solitary and rounded cyanobacteria Synechocystis sp. was the most representative (abundance) in Lake La Luna; its small cell size $(<2 \mu \mathrm{m})$ results in a high surface to volume ratio that favors nutrient absorption by diffusion, an advantage under low nutrient concentrations, such as in Lake La Luna. Small cells facilitate the transfer of nutrients to higher trophic levels and therefore are a very important link in the trophic web of ultra-oligotrophic systems [84].

The predominance of Chlorophyceae, mainly Chlorococcal, in Lake El Sol agrees with its oligotrophic status [84], indicating photosynthesis is more important than mixotrophy. In contrast, in the ultraoligotrophic Lake La Luna, mixotrophy results in a more important process.

The differences in the phytoplankton species richness of Lakes El Sol and La Luna could be associated with the interplay of the following main drivers, which showed differences between both lakes and pose a challenge to phytoplankton development: [a] lake area, [b] presence/absence of macrophytes, [c] trophic status, [d] pH, [e] ultraviolet radiation (UVR), and [f] exotic fish introduction. However, not all variables have the same importance in controlling the phytoplankton community. First, the magnitude of the laketo-lake difference of each variable differs, and second, the magnitude of the effect of each variable on phytoplankton also differs. Therefore, the result expressed in the phytoplankton community derives from the interaction of the variables that probably act synergistically in some cases, while antagonistically in others.

(a) Lake area. The area-species richness relationship is well-known [1,2]. Lake area is closely related to habitat diversity and then higher species richness [3]. The surface of Lake El Sol is almost eight times larger than Lake La Luna [23]. Additionally, Lake El Sol is deeper and holds a larger water volume than Lake La Luna.

(b) Macrophytes. The presence and development of macrophytes are important in influencing phytoplankton biodiversity [85]. Lake El Sol displays an extended vegetated area (e.g., Chara) on the shallow littoral, while Lake La Luna has no macrophytes. While macrophytes compete with phytoplankton and reduce its biodiversity [86], macrophytes also provide microhabitats that harbor benthic diatoms that eventually incorporate into the water column, augmenting the taxonomic richness found in phytoplankton. To date, empirical evidence shows that the number of habitats in a region is almost always positively correlated with the number of species inhabiting it [3]. In fact, habitat diversity is often a better predictor of species richness than area $[87,88]$.

(c) Trophic status. An inverse relationship has been found between trophic status and phytoplankton biodiversity [4-6]. However, this relationship is expressed when comparing oligo- versus eutrophic lakes. The trophic (chlorophyll and nutrient concentrations) difference between Lakes El Sol and La Luna is marginal since the former is oligotrophic and the latter ultraoligotrophic. Phytoplankton in both lakes are restricted by the low nutrient concentration.

(d) $\mathrm{pH}$ value. Acidification of HML diminishes phytoplankton biodiversity $[9,10]$. Both lakes have acid $\mathrm{pH}$ values. However, $\mathrm{pH}$ in Lake La Luna $(4.7 \pm 0.3)$ is lower than in Lake El Sol (5.4 \pm 0.4 ), reaching limiting values for biota distribution [23,29].

(e) UV radiation. UVR at HML is higher than at sea level, and often HML are transparent (oligotrophic) and with scarce UVR attenuation substances (e.g., chromophoric dissolved organic matter) negatively impacting phytoplankton biodiversity $[7,8]$. The light attenuation coefficient $(\mathrm{Kd})$ is lower in Lake La Luna $\left(0.21 \pm 0.06 \mathrm{~m}^{-1}\right)$ than in Lake El Sol $\left[0.37 \pm 0.07 \mathrm{~m}^{-1}\right]$, mirroring the higher turbidity of Lake El Sol compared 
to Lake La Luna. Consequently, UVR reaches all of the water column, down to the lake's bottom in Lake La Luna, while in Lake El Sol, UVR is attenuated in the top 25\% of the water column. This translated into an inexistent depth refuge (UVR safe zone $0 \%$ of the water column) in Lake La Luna, while larger (UVR safe zone $75 \%$ of the water column) in Lake El Sol [89].

(f) Exotic fish species introduction. During the 1950's there was a successful rainbow trout introduction in Lake El Sol that failed in Lake La Luna [31]. Fish introduction is associated with biodiversity loss in shallow lakes [11,12,90,91]. However, phytoplankton biodiversity in fish-stocked Lake El Sol was higher than in fishless Lake La Luna. In addition to promoting turbidity, rainbow trout also change the food webs, generate trophic cascade effects, and change the plankton functional groups with Cyanobacteria as a dominant group in fish-stocked lakes [92-94]. However, phytoplankton biodiversity in fish-stocked Lake El Sol was higher than in fishless Lake La Luna.

The reported effects of these drivers on biodiversity match our findings in some cases, while they did not in others (Table 6).

Table 6. Theoretical positive (+) and negative (-) effects of the main phytoplankton biodiversity drivers, and actual findings ( $\boldsymbol{V}$ match, $\mathrm{X}$ no match) of the phytoplankton biodiversity of Lakes El Sol and La Luna.

\begin{tabular}{|c|c|c|c|c|c|c|c|}
\hline & \multirow{2}{*}{$\begin{array}{c}\text { Surface } \\
\text { Area }\end{array}$} & \multicolumn{2}{|c|}{ Macrophytes } & \multirow{2}{*}{$\begin{array}{l}\text { Trophic } \\
\text { Status }\end{array}$} & \multirow{2}{*}{$\mathrm{pH}$} & \multirow{2}{*}{ UVR } & \multirow{2}{*}{$\begin{array}{c}\text { Fish } \\
\text { Introduction }\end{array}$} \\
\hline & & Coverage & Microhabitats & & & & \\
\hline Theoretical & + & - & + & - & + & - & - \\
\hline Actual & $\checkmark$ & $x$ & $\checkmark$ & $x$ & $\checkmark$ & $\checkmark$ & $x$ \\
\hline
\end{tabular}

Additionally, it seems Lake El Sol could be in a transitional stage between the clearwater (macrophyte dominated) and the turbid-water (phytoplankton dominated) states described as alternative stable states for shallow lakes. Regarding nutrient concentrations, there is a subtle difference between the trophic status of Lake La Luna (ultraoligotrophic) and Lake El Sol (oligotrophic). Concerning the effects of fish introduction on the ecosystem, the zooplankton of the fishless Lake La Luna is much larger than in the fish stocked Lake El Sol [89], suggesting rainbow trout is indeed affecting the plankton composition, as found by Lancelotti et al. [94] and others. Nonetheless, the rainbow trout abundance in Lake El Sol is unknown, so we do not know the actual effect on the trophic cascade.

Finally, the low $\mathrm{pH}$ combined with the high incident UVR could be the most important drivers in reducing phytoplankton diversity in Lake La Luna, as previously suggested for the zooplankton assemblage by Dimas-Flores et al. [26], while in Lake El Sol, the less extreme $\mathrm{pH}$ and higher turbidity that serve as protection against UVR, promote the phytoplankton diversity.

\section{Conclusions}

The phytoplankton species richness of Lakes El Sol and La Luna was higher than those reported for other tropical and temperate HMLs. The most diverse phytoplankton groups were Bacillariophyceae and Chlorophyceae. Most diatoms were tychoplanktonic, associated with the lakes' shallowness and warm polymictic regime. Regarding abundance, the Chlorophyte Oocystis lacustri was the dominant species in Lake El Sol, while the Cyanobacteria Synechocystis sp. in Lake La Luna. Regarding biomass, the Chlorophytes in Lake El Sol, and the dinoflagellates and Cyanobacteria in Lake Luna were dominant. The Chlorococales characterized the oligotrophic Lake El Sol and the Cyanobacteria the ultraoligotrophic Lake La Luna. The larger phytoplankton species richness, density, and biomass in Lake El Sol than in Lake La Luna seems to be explained by the most extreme conditions in Lake La Luna expressed by its lower $\mathrm{pH}$ and the higher doses of UVR 
associated with its higher transparency. A larger habitat diversity in Lake El Sol resulted from its larger area, and the presence of submersed macrophytes promotes phytoplankton species richness.

Supplementary Materials: The following supporting information can be downloaded at: https:/ / www.mdpi.com/article/10.3390/d14010042/s1, Table S1: Global density (cells mL ${ }^{-1}$ ) and biovolume $\mathrm{mm}^{3} \mathrm{~m}^{-3}$ ) of the phytoplankton taxa recorded in Lakes El Sol and La Luna, Nevado de Toluca. (Navicula NTA and N. NTB according [12]). (NF = not found).

Author Contributions: Conceptualization, E.C., J.A., M.G. and M.C.; methodology, E.C. and J.A.; software, E.C.; validation, E.C., M.G. and M.C.; formal analysis, E.C., J.A., M.G. and M.C.; investigation, E.C. and J.A.; resources, J.A.; data curation, E.C. and M.C.; writing-original draft preparation, E.C. and J.A.; writing—review and editing, E.C., J.A., M.G. and M.C.; visualization, E.C., J.A., M.G. and M.C.; supervision, E.C., J.A., M.G. and M.C.; project administration, J.A.; funding acquisition, J.A. All authors have read and agreed to the published version of the manuscript.

Funding: This research was funded the Fondo Sectorial de Investigación Ambiental SEMARNATCONACYT 2015 through project 262970, the Universidad Nacional Autónoma de México DGAPA/ PAPIIT through projects ES209301, and Programa de Investigación en Cambio Climático (PINCC 2012-2014 and 2020-2021).

Institutional Review Board Statement: Not applicable.

Informed Consent Statement: Not applicable.

Data Availability Statement: Data are available from the authors upon reasonable request.

Acknowledgments: The Comisión Estatal de Parques Naturales y de la Fauna (CEPANAF, Secretaría de Ecología, Gobierno del Estado de México) provided the permit for scientific research at the Área de Protección de Flora y Fauna Nevado de Toluca. We thank Luis A. Oseguera for support during the field work.

Conflicts of Interest: The authors certify that they have no affiliations with or involvement in any organization or entity with any financial interest [such as honoraria; educational grants; participation in speakers' bureaus; membership, employment, consultancies, stock ownership, or other equity interest; and expert testimony or patent-licensing arrangements] or non-financial interest [such as personal or professional relationships, affiliations, knowledge or beliefs] in the subject matter or materials discussed in this manuscript.

\section{References}

1. Søndergaad, M.; Jeepesen, E.; Jensen, J.P. Pond or lake: Does it make any difference? Arch. Hydrobiol. 2005, 162, 143-165. [CrossRef]

2. Stomp, M.; Huisman, J.; Mittelbach, G.G.; Litchman, E.; Klausmeier, C.A. Large-scale biodiversity patterns in freshwaters phytoplankton. Ecology 2011, 92, 2096-2107. [CrossRef] [PubMed]

3. Triantis, K.A.; Mylonas, M.; Weiser, M.D.; Lika, K.; Vardinoyannis, K. Species richness, environmental heterogeneity and area: A case study based on land snails in Skyros Archipelago (Aegean Sea, Greece). J. Biogeogr. 2005, 32, 1727-1735. [CrossRef]

4. Baho, D.L.; Drakare, S.; Johnson, R.K.; Allen, C.R.; Angeler, D.G. Is the impact of eutrophication on phytoplankton diversity dependent on lake volume/ecosystem size? J. Limnol. 2017, 76, 199-210. [CrossRef]

5. Brahney, J.; Mahowald, N.; Ward, D.S.; Ballantyne, A.P.; Neff, J.C. Is atmospheric phosphorus pollution altering global alpine Lake stoichiometry? Glob. Biochem. Cycles 2015, 29, 1369-1383. [CrossRef]

6. Kissman, C.E.H.; Willams, C.E.; Rose, K.C.; Saros, J.E. Response of phytoplankton in an alpine lake to inputs of dissolved organic matter through nutrient enrichment and trophic forcing. Limnol. Oceanogr. 2013, 58, 867-880. [CrossRef]

7. Sommaruga, R.; Gunter, A. Seasonality in UV transparency of an alpine lake is associated to changes in phytoplankton biomass. Aquat. Sci. 2006, 68, 129-141. [CrossRef]

8. Korbee, N.; Carrillo, P.; Mata, M.T.; Rosillo, S.; Medina-Sánchez, J.M.; Figueroa, F.L. Effect of ultraviolet radiation and nutrients on structure-function of phytoplankton in a high mountain lake. Photochem. Photobiol. Sci. 2012, 11, 1087-1098. [CrossRef] [PubMed]

9. Tolotti, M. Phytoplankton and littoral epilithic diatoms in high mountain lakes of the Adamello-Brenta Regional Park (Trentino, Italy) and their relation to trophic status and acidification risk. J. Limnol. 2001, 60, 171-188. [CrossRef]

10. Triadó-Margarit, X.; Casamayor, E. Genetic diversity of planktonic eukaryotes in high mountain lakes (Central Pyrenees, Spain). Environ. Microbiol. 2012, 14, 2445-2456. [CrossRef] 
11. Tiberti, R.; Hardenberg, A.; Bogliani, G. Ecological impact of introduced fish in high altitude lakes: A case of study from European Alps. Hidrobiologia 2013, 724, 1-19. [CrossRef]

12. Cantonati, M.; Zorza, R.; Bertoli, M.; Pastorino, P.; Salvi, G.; Platania, G.; Prearo, M.; Pizzul, E. Recent and subfossil assemblages as indicator of environmental change (including fish introduction in a high-mountain lake). Ecol. Indic. 2021, 125, 107603. [CrossRef]

13. Catalan, J.; Camarero, L.; Felip, M.; Pla, S.; Ventura, M.; Buchaca, T.; Bartumeus, F.; Mendoza, G.D.; Miró, A.; Casamayor, E.O.; et al. High mountain lakes: Extreme habitats and witnesses of environmental changes. Limnetica 2006, 25, 551-584. [CrossRef]

14. Pastorino, P.; Prearo, M. High-Mountain Lakes, Indicators of Global Change: Ecological characterization and environmental pressures. Diversity 2020, 12, 260. [CrossRef]

15. Löffler, H. Aspects of the history and evolution of alpine lakes in Austria. Hydrobiologia 1983, 100, 143-152. [CrossRef]

16. Ortiz-Álvarez, R.; Triadó-Margarit, X.; Camareno, L.; Casamayor, E.O.; Catalan, J. High planktonic diversity in mountain lakes contains similar contributions of autotrophic, heterotrophic and parasitic eukaryotic life forms. Sci. Rep. 2018, 8, 4457. [CrossRef] [PubMed]

17. Pastorino, P.; Elia, A.C.; Caldaroni, B.; Menconi, V.; Abete, M.C.; Brizia, P.; Bertoli, M.; Zaccaroni, A.; Gabriele, M.; Dörr, A.J.M.; et al. Oxidative stress ecology in brook trout (Salvelinus fontinalis) from a high-mountain lake (Cottian Alps). Sci. Total Environ. 2020, 715, 136946. [CrossRef] [PubMed]

18. Catalan, J.; Donato Rondón, J.C. Perspectives for an integrated understanding of tropical and temperate high-mountain lakes. J. Limnol. 2016, 75, 215-234. [CrossRef]

19. Casallas, J.; Gunkel, G. Algunos aspectos limnológicos de un lago altoandino, el Lago San Pablo, Ecuador. Limnetica 2001, 20, 29-46. [CrossRef]

20. Llorente-Bousquets, J.; Ocegueda, S. Estado del conocimiento de la biota. In Capital Natural de México, Vol. 1. Conocimiento Actual de la Biodiversidad; Conabio, Ed.; Comisión Nacional para el Conocimiento y Uso de la Biodiversidad: Ciudad de México, Mexico, 2008; pp. 283-322.

21. Lewis, W.M., Jr. Tropical limnology. Annu. Rev. Ecol. Evol. Syst. 1987, 18, 159-184. [CrossRef]

22. Armienta, M.A.; de la Cruz-Reina, S.; Macias, J.L. Chemical characteristics of the crater lakes of Popocatepetl, El Chichón and Nevado de Toluca volcanoes. J. Volcanol. Geotherm. Res. 2000, 97, 105-125. [CrossRef]

23. Alcocer, J.; Oseguera, L.A.; Escobar, E.; Peralta, L.; Lugo, A. Phytoplankton biomass and water chemistry in two high mountain tropical lakes in Central Mexico. Arct. Antarct. Alp. Res. 2004, 36, 342-346. [CrossRef]

24. Elías-Gutiérrez, M.; Ciros-Pérez, J.; Gutiérrez-Aguirre, M.; Cervantes-Martínez, A. A checklist of the littoral cladocerans from Mexico, with descriptions of five taxa recently recorded from the Neovolcanic Province. Hydrobiologia 1997, 360, 63-73. [CrossRef]

25. Sarma, S.S.; Elías-Gutiérrez, M.; Serranía Soto, C. Rotifers from high altitude crater-lakes at Nevado de Toluca volcano, México. Hidrobiológica 1997, 6, 33-38.

26. Dimas-Flores, N.; Alcocer, J.; Ciros-Pérez, J. The structure of the zooplankton assemblages from two neighboring tropical high mountain lakes. J. Fresh Water Ecol. 2008, 23, 21-31. [CrossRef]

27. Oseguera, L.A.; Alcocer, J.; Escobar, E. Macroinvertebrados bentónicos de dos lagos tropicales de alta montaña en el volcán Nevado de Toluca, en el centro de México. Hidrobiológica 2016, 26, 419-432.

28. Löffler, H. Contribution to the limnology of high mountain lakes in Central America. Int. Rev. Gesamten Hydrobiol. 1972, 57, 397-408. [CrossRef]

29. Caballero-Miranda, M. The diatom flora of two acid lakes in central Mexico. Diatom Res. 1996, 11, 227-240. [CrossRef]

30. Banderas-Tarabay, A.G. Phycoflora of the tropical high mountain lake El Sol, Central Mexico, and some biogeographical relationships. Hydrobiologia 1997, 354, 17-40. [CrossRef]

31. Cuna, E.; Zawisza, E.; Caballero, M.; Ruiz-Fernández, A.C.; Lozano-García, M.S.; Alcocer, J. Environmental impact of the Little Ice Age cooling in Central Mexico: The record from a tropical alpine lake. J. Paleolimnol. 2014, 51, 1-14. [CrossRef]

32. SMN-CONAGUA. Servicio Meteorológico Nacional, Comisión Nacional del Agua. 2017. Available online: http://smn1.conagua gob.mx/emas (accessed on 6 January 2022).

33. Alcocer, J.; Roberson, J.; Oseguera, L.A.; Lewis, M.W., Jr. Rhythmic episodes of heating and cooling control thermal stratification of two tropical high mountain lakes. Aquat. Sci. 2020, 82, 58. [CrossRef]

34. Batarbe, R.W. Diatom analysis. In Handbook of Holocene Palaeoecology and Palaeohydrology; Berlung, E.B., Ed.; John Wiley \& Sons: Chichester, UK, 1986; pp. 423-448.

35. Comas, A. Las Chlorococcales Dulceacuícolas de Cuba. Biblioteca Phicologica Band 99; J. Cramer: Berlin, Germany; Stuttgart, Germany, 1996.

36. Desikachary, T.V. Cyanophyta; I.C.A.R.: New Delhi, India, 1959.

37. Dillar, G.E. Freshwater Algae of the Southeastern United States, Part 1; J. Cramer: Berlin, Germany; Stuttgart, Germany, 1989.

38. Dillar, G.E. Freshwater Algae of the Southeastern United States, Part 3 (Section 2); J. Cramer: Berlin, Germany; Stuttgart, Germany, 1990.

39. Dillar, G.E. Freshwater Algae of the Southeastern United States, Part 4 (Section 4); J. Cramer: Berlin, Germany; Stuttgart, Germany, 1991.

40. Dillar, G.E. Freshwater Algae of the Southeastern United States, Part 6 (Section 4); J. Cramer: Berlin, Germany; Stuttgart, Germany, 1993.

41. Ettl, H.; Gärtner, G. Sußwasserflora von Mitteleuropa. Chlorophyta II. Band 10: Tetrasporales, Chlorococcales, Gloeodendrales; Gustav Fischer Verlag: Stuttgart, Germany; New York, NY, USA, 1988.

42. Huber-Pestalozzi, G. (Grünalgen) Ordnung: Volvocales; E. Schweizerbart'sche Verlagsbuchhandlung: Stuttgart, Germany, 1961. 
43. Huber-Pestalozzi, G. Das Phytoplankton des Süßwassers Systematik und Biologic. 2 Teil Chrysophyceen. Farblose Flagellaten Heterokonten; E. Schweizerbart'sche Verlagsbuchhandlung: Stuttgart, Germany, 1962.

44. Huber-Pestalozzi, G. Das Phytoplankton des Süßwassers Systematik und Biologic. 3 Teil Chryptophyceae, Chloromonadaceae, Dinophyceae; E. Schweizerbart'sche Verlagsbuchhandlung: Stuttgart, Germany, 1968.

45. Komárek, J.; Anagnostidis, K. Cyanoprokaryota 1. Teil: Chroococcales; Gustav Fischer: Jena, Germany; Stuttgart, Germany; Lübeck, Germany; Ulm, Germany, 1999.

46. Komárek, J.; Fott, B. Chlorophyceae. (Güelgen). Ordnurg: Chlorococccales. 7/1. 16. Das Phytoplankton des Sübwassers, Systematick und Biologie. Die Binnengëwasser; Huber-Pestalozzi, G., Ed.; E. Schweizerbart'sche Stuttgart Verlagsbuchhandlung: Stuttgart, Germany, 1983.

47. Krammer, K.; Lange-Bertalot, H. Süßwasser Flora von Mitteleuropa. Band 2/1: Bacillariophyceae. 2. Teil: Naviculaceae; Gustav Fisher: Jena, Germany, 1986.

48. Krammer, K.; Lange-Bertalot, H. Süßwasser Flora von Mitteleuropa. Band 2/2: Baccillariophyceae (Epithemiaceae, Surirellaceae); Gustav Fisher: Jena, Germany, 1988.

49. Krammer, K.; Lange-Bertalot, H. Süßwasser Flora von Mitteleuropa. Band 2/2: Baccillariophyceae (Centrales, Fragilariaceae, Eunotiacea); Gustav Fisher: Jena, Germany, 1991.

50. Krammer, K.; Lange-Bertalot, H. Süßwasser Flora von Mitteleuropa. Band 2/4: Baccillariophyceae (Achnanthes, Kristiche Ergannzunge zu Navicula (Lineolatae) und Gomphonema); Gustav Fisher: Jena, Germany, 1991.

51. Philipose, M.D. Chlorococcales; Indian Council of Agricultural Research: New Delhi, India, 1967.

52. Popovský, J.; Pfiester, L.A. Subeasserflora von Mitteleuropa, Band 6, Dinophyceae (Dinoflagellida); Gustav Fischer Verlag: Jena, Germany; Stuttgart, Germany, 1990.

53. Prescott, G.W.; Croasdale, H.T.; Vinyard, W.C. A Synopsis of North American Desmids. Part II, Section I; University of Nebraska Press: Lincoln, NE, USA, 1975.

54. Prescott, G.W.; Croasdale, H.T.; Vinyard, W.C. A Synopsis of North American Desmids. Part II, Section 2; University of Nebraska Press: Lincoln, NE, USA, 1977.

55. Prescott, G.W.; Croasdale, H.T.; Vinyard, W.C.; Bicudo, C.E. A Synopsis of North American Desmids. Part II, Section 3; University of Nebraska Press: Lincoln, NE, USA, 1981.

56. Guiry, M.D.; Guiry, G.M. AlgaeBase. World-Wide Electronic Publication; National University of Ireland: Galway, Ireland, 2019; Available online: http:/ / www.algaebase.org (accessed on 21 July 2019).

57. Wetzel, R.G.; Likens, G.E. Limnological Analysis; Springer: New York, NY, USA, 2000.

58. Sun, J.; Liu, D. Geometric models for calculating cell biovolume and surface area for phytoplankton. J. Plankton Res. 2003, 25, 1331-1346. [CrossRef]

59. Hutchinson, G.E. A Treatise on Limnology. Volume II. Introduction to Lake Biology and Limnoplankton; Wiley: New York, NY, USA, 1967.

60. Margulis, L.; Chapman, M.J. Kingdoms and Domains: An Illustrated Guide to the Phyla of Life on Earth; Academic Press/Elsevier: Amsterdam, The Netherlands, 2009; 566p, ISBN 978-0123736215.

61. Sokal, R.R.; Rohlf, F.J. Biometry: The Principles and Practice of Statistics in Biological Research; W.H. Freeman: San Francisco, CA, USA, 1981; 859p.

62. Pedroche, F.F.; Dreckmann, K.M.; Sentíes, G.A.; Margain-Hernández, R. Diversidad algal en México. Rev. Soc. Mex. Hist. Nat. 1993, XLIV, 69-92.

63. Oliva-Martínez, M.G.; Godínez-Ortega, J.L.; Zuñiga-Ramos, C.A. Biodiversidad del fitoplancton de aguas continentales en México. Rev. Mex. Biodivers. 2014, 85, 54-61. [CrossRef]

64. Vilaclara, G.; Cuna, E.; Zeeb, B. Subfossil chrysophyte cyst morphotypes from two tropical, high-mountain lakes in Nevado de Toluca volcano, Central Mexico. Nova Hedwig. 2005, 128, 309-335.

65. Reynolds, C. The concept of ecological succession applied to seasonal periodicity of freshwater phytoplankton. Verh. Des Int. Ver. Limnol. 1988, 23, 683-691. [CrossRef]

66. Garduño-Solórzano, G.; Martínez-García, M.; Scotta Hentschke, G.; Lopes, G.; Castelo Branco, R.; Oliveira Vasconcelos, V.M.; Campos, J.E.; López-Cano, R.; Quintanar-Zúñiga, R.E. The phylogenetic placement of Temnogametum (Zygnemataceae) and description of Temnogametum iztacalense sp. nov., from a tropical high mountain lake in Mexico. Eur. J. Phycol. 2021, 56, 159-173. [CrossRef]

67. Cervantes-Martínez, A.; Gutiérrez-Aguirre, M.; Elías-Gutiérrez, M. Description of Iliocryptus nevadensis (Branchiopoda, Anomopoda), a new species from high altitude crater lake in the volcano Nevado de Toluca, Mexico. Crustaceana 2000, 354, 311-321.

68. Sinev, A.Y.; Zawisza, E. Comments on cladocerans of crater lakes of the Nevado de Toluca Volcano (Central Mexico), with the description of a new species, Alona manueli sp. nov. Zootaxa 2013, 3647, 390-400. [CrossRef] [PubMed]

69. Lewis, W.M., Jr. Global primary production of lakes: 19th Baldi Memorial Lecture. Inland Waters 2011, 1, 1-28. [CrossRef]

70. Garduño Solórzano, G.; Oliva Martínez, M.G.; Ortega, M. Algas. In La Diversidad Biológica del Estado de México. Estudio de Estado Ceballos, G., List, R., Garduno, G., López Cano, R., Muñozcano Quintanar, M.J., Collado, E., San Román, J.E., Eds.; Colección Mayor, Gobierno del Estado de Mexico, CONABIO: Mexico City, Mexico, 2009; pp. 153-161. 
71. Godínez-Ortega, J.L.; Oliva-Martínez, M.G.; Escobar-Oliva, M.A.; Mendoza-Garfias, M.B. Diversidad algal del Parque Nacional Lagunas de Zempoala, México, excepto diatomeas. Hidrobiológica 2017, 27, 45-58. [CrossRef]

72. León López, N.; Rivera Rondón, C.A.; Zapata, A.; Jiménez, J.; Villamil, W.; Arenas, G.; Rincón, C.; Sánchez, T. Factors controlling phytoplankton in tropical high-mountain drinking-water reservoirs. Limnetica 2012, 31, 305-322. [CrossRef]

73. Krupa, E.G.; Barinova, S.M.; Romanova, S.M.; Malybekov, A.B. Hydrobiological assessment of the high mountain Kolsay lakes (Kungey Alatau, Southeastern Kazakhstan) ecosystems in climatic gradient. Br. J. Environ. Clim. Chang. 2016, 6, 259-278. [CrossRef]

74. Simona, M.; Barbieri, A.; Veronesi, M.; Malusardi, S.; Straškrabová, V. Seasonal Dynamics of plankton in a mountain lake in the southern Alps (Laghetto Inferiore, Switzerland). J. Limnol. 1999, 58, 169-178. [CrossRef]

75. Fott, J.; Blažo, M.; Stuchlík, E.; Strunecký, O. Phytoplankton in three Tatra Mountain lakes of different acidification status. J. Limnol. 1999, 58, 107-116. [CrossRef]

76. Hillebrand, H. On the generality of the latitudinal diversity gradient. Am. Nat. 2004, 163, 192-211. [CrossRef] [PubMed]

77. Willig, M.R.; Kaufman, D.M.; Stevens, R.D. Latitudinal gradients of biodiversity: Pattern, process, scale and synthesis. Annu. Rev. Ecol. Evol. Syst. 2003, 34, 273-309. [CrossRef]

78. Polato, N.R.; Gill, B.A.; Shah, A.A.; Gray, M.M.; Casner, K.L.; Barthelet, A.; Messer, P.W.; Simmons, M.P.; Guayasamin, J.M.; Encalada, A.C.; et al. Narrow thermal tolerance and low dispersal drive higher speciation in tropical mountains. Proc. Natl. Acad. Sci. USA 2018, 115, 12471-12476. [CrossRef]

79. Usinowicz, J.; Chang-Yang, C.; Chen, Y.; Clark, J.S.; Fletcher, C.; Garwood, N.C.; Hao, Z.; Johnstone, J.; Lin, Y.; Metz, M.R.; et al. Temporal coexistence mechanisms contribute to the latitudinal gradient in forest diversity. Nature 2017, 550, 105-108. [CrossRef]

80. Novelo, E.; Tavera, R. Un panorama gráfico de las algas de agua dulce de México. Hidrobiológica 2011, 21, 333-341.

81. Rivera, C.; Solano, D.; Zapata, A.; Donato, J. Phytoplankton diversity in a tropical high mountain lake. Verh. Int. Ver. Theor. Angew. Limnol. 2005, 29, 418-421. [CrossRef]

82. Tolotti, M.; Thies, H.; Cantonati, M.; Hansen, C.; Thaler, B. Flagellate algae (Chrysophyceae, Dinophyceae, Cryptophyceae) en 48 high mountain lakes of the Northern and Southern slope of the Eastern Alps: Biodiversity, taxa distribution and their driving variables. Hydrobiologia 2001, 502, 331-348. [CrossRef]

83. Unrein, F.; Massana, R.; Alonso-Saénz, L.; Gasol, J.M. Significant year-round of small mixotrophic flagellates on bacterioplankton in an oligotrophic coastal system. Limnol. Oceanogr. 2007, 52, 456-469. [CrossRef]

84. Reynolds, C.S. What factors influence the species composition of phytoplankton in lakes of different trophic status. Hydrobiologia 1998, 369, 11-26. [CrossRef]

85. Porcel, S.; Chaparro, G.; Marinone, M.C.; Saad, J.F.; Lancelotti, J.; Izaguirre, I. The role of environmental, geographical, morphometric and spatial variables on plankton communities in lakes of the arid Patagonian plateau. J. Plankton Res. 2020, 42, $173-187$. [CrossRef]

86. Kufel, L.; Kufel, I. Chara beds acting as nutrient sinks in shallow lakes-A review. Aquat. Bot. 2002, 72, 249-260. [CrossRef]

87. Hortal, J.; Triantis, K.; Meiri, S.; Thebault, E.; Sfenthourakis, S. Island species richness increases with hábitat diversity. Am. Nat. 2009, 174, E205-E217. [CrossRef]

88. Triantis, K.A.; Nogués-Bravo, D.; Hortal, J.; Borges, P.A.; Adsersen, H.; Fernández-Palacios, J.M.; Araujo, M.B.; Whittaker, R.J. Measurements of area and the (island) species area relationship: New direction for old pattern. Oikos 2008, 117, 1555-1559. [CrossRef]

89. Alcocer, J.; Delgado, C.N.; Sommaruga, R. Photoprotective compounds in zooplankton of two adjacent tropical high mountain lakes with contrasting underwater light climate and fish occurrence. J. Plankton Res. 2020, 42, 105-118. [CrossRef]

90. Izaguirre, I.; Lancelotti, J.; Saad, J.F.; Porcel, S.; O'Farrell, I.; Marinone, M.C.; Roesler, I.; Dieguez, M.C. Influence of fish introduction and water level decrease on lakes of the arid Patagonian plateaus with importance for biodiversity conservation. Glob. Ecol. Conserv. 2018, 14, e00391. [CrossRef]

91. Pastorino, P.; Prearo, M.; Bertoli, M.; Menconi, V.; Esposito, G.; Righetti, M.; Mugetti, D.; Pederiva, S.; Abete, M.C.; Pizzul, E. Assessment of biological and sanitary condition of alien fish from a high-mountain lake (Cottian Alps). Water 2020, 12, 559. [CrossRef]

92. Izaguirre, I.; Saad, J.F. Phytoplankton from natural water bodies of Patagonian plateau. Adv. Limnol. 2014, 65, 309-319. [CrossRef]

93. Lancelotti, J.L.; Marinone, M.C.; Roesler, I. Rainbow trout effects on zooplankton in the reproductive area of the critically endangered hooded grebe. Aquat. Conserv. Mar. Freshw. Ecosyst. 2016, 27, 128-136. [CrossRef]

94. Saad, J.F.; Porcel, S.; Lancelotti, J.; O’Farrel, I.; Izaguirre, I. Both lake regime and fish introduction shape autotrophic planktonic communities of lakes from the Patagonian plateau (Argentina). Hydrobiologia 2018, 831, 133-145. [CrossRef] 